\title{
CATABOLISM OF CAFFEINE AND PURIFICATION OF A XANTHINE OXIDASE RESPONSIBLE FOR METHYLURIC ACIDS PRODUCTION IN PSEUDOMONAS PUTIDA L
}

\author{
Dirce Mithico Yamaoka-Yano, Paulo Mazzafera* \\ Departamento de Fisiologia Vegetal, Instituto de Biologia, Universidade Estadual de Campinas, Campinas, \\ SP, Brasil.
}

Submitted: April 17, 1998; Returned to authors for corrections: July 27, 1998; Approved: January 04, 1999.

\begin{abstract}
Caffeine catabolism and a xanthine oxidase involved in the alkaloid breakdown were studied in Pseudomonas putida L, a strain displaying high ability to grow on this substrate. Cells cultured with unlabelled caffeine and ${ }^{14} \mathrm{C}$ labeled caffeine and xanthine showed that this alkaloid was broken-down via theobromine/paraxanthine -> 7-methylxanthine -> xanthine $->$ uric acid $->$ allantoin $->$ allantoic acid. Methyluric acids were formed from the oxidation of theobromine, paraxanthine and 7-methylxanthine, although no bacterial growth was observed on these compounds, indicating that this might be due to a wide substrate specificity of xanthine oxidase. This was confirmed by activity staining in PAGE where activity was observed with theophylline and 3-methylxanthine, which are not involved in the alkaloid breakdown. A single band of activity was detected without addition of $\mathrm{NAD}^{+}$, showing an oxidase form of the enzyme. The enzyme optimum temperature and $\mathrm{pH}$ were $30^{\circ} \mathrm{C}$ and 7.0 , respectively. The determined $K_{\mathrm{m}}$ was $169 \mu \mathrm{M}$, and the $\mathrm{pI} 3.1$ 4.0. The molecular weight determined by side by side comparison of activity staining of the enzyme in PAGE and PAGE of BSA was $192 \mathrm{kDa}$, which was coincident with the sum $(198.4 \mathrm{kDa})$ of three subunits $(71,65.6$ and $61.8 \mathrm{kDa})$ of the purified protein.
\end{abstract}

Key- words: caffeine, methylpurines, methyluric acids, Pseudomonas, xanthine oxidase.

\section{INTRODUCTION}

Woolfolk (15) was the first to investigate caffeine degradation by Pseudomonas putida. A previous comprehensive review on the degradation of purine and structure-related compounds by microorganisms (14) did not indicate any other report. However, it is worth mentioning that Dikstein et al. (5) observed that 3-methylxanthine, but not 1-methylxanthine, was dehydrogenated to the corresponding methyluric acid in protein preparations from fluorescent Pseudomonas.

Woolfolk (15) suggested that caffeine was hydrolytically $N$-demethylated, with the production of free xanthine and methanol. The alcohol was further oxidized to $\mathrm{CO}_{2}$ and xanthine to uric acid. Dimethylxanthines and monomethylxanthines would be also converted to their respective methyluric acids.

The metabolism of caffeine by a $P$. putida strain was investigated by Blecher and Lingens (4). The

\footnotetext{
" Corresponding author. Mailing address: Departamento de Fisiologia Vegetal, Instituto de Biologia, Caixa Postal 6109, Universidade Estadual de Campinas, CEP 13083-970, Campinas, SP, Brazil. Fax: (+5519) 289-3124; E-mail: pmazza@obelix.unicamp.br.
} 
bacteria was isolated in a complex medium, containing different sources of carbon and nitrogen, supplemented with the alkaloid. The complete pathway for caffeine degradation was established (Fig. 1) by culturing the bacteria with several substrates in mineral salts medium (without any nitrogen or carbon source) and the subsequent identification of the products released in the culture media. It was also shown that instead of methanol, the methyl groups were splitted off as formaldehyde. A similar pathway was also observed to occur in Serratia marcescens isolated from soil cultivated with coffee (9).

Ten years latter this subject was retaken by Glück and Lingens (6), but now focussed on the production of demethylated caffeine derivatives using the same P. putida isolated by Blecher and Lingens (4). Similarly, Asano et al. (1) isolated a P. putida strain that, cultivated in the presence of $\mathrm{Zn}^{2+}$, accumulated theobromine formed from caffeine, with a yield of $92 \%$.

The Pseudomonas strains used by Woolfolk (15), Blecher and Lingens (4) and Asano et al. (1) in their studies were also isolated after several transfers in complex media suplemented with caffeine. Middelhoven and Lommen (10) also used the same procedure to isolate a $P$. putida which grew in mineral salts medium supplemented with $5 \mathrm{~g} / 1$ of caffeine. Recently we have isolated a $P$. putida strain from soil collected under coffee trees, without such long term enrichment, suggesting its adaptation to continuous exposure to the caffeine released from the coffee trees (18). Our strain could grow in mineral salts liquid and solid media, containing $20 \mathrm{~g} / 1$ and $50 \mathrm{~g} / \mathrm{l}$ of caffeine.

Since this strain showed an considerable higher ability to grow on caffeine than previous reports in the literature, the aim of this work was to study the pathway for the alkaloid degradation, and the characterization and purification of the xanthine oxidase responsible for the oxidation of methylxanthines and xanthine produced during the alkaloid demethylation. To our knowledge, this enzyme has never been studied in caffeine degrading microorganisms.

\section{MATERIALS AND METHODS}

Bacteria and chemicals - All chemicals and solvents were purchased from Sigma or Merck. $\left[{ }^{14} \mathrm{C}-2\right]$ Caffeine was produced by methylation of $\left[{ }^{14} \mathrm{C}-2\right]$ xanthine $(1.94$ $\mathrm{Gbq} / \mathrm{mmol}$, Sigma St. Louis, USA) (7). P. putida strain
L isolated by Yamaoka-Yano and Mazzafera (18) was used in this study. The bacteria was stored in skin-milk at $-20^{\circ} \mathrm{C}$ and, when used, it was plated on solid M9 medium (12) with caffeine $(0.3 \mathrm{~g} / \mathrm{l})$ as the only source of carbon and nitrogen (M9-CAF). The plates were kept at $28^{\circ} \mathrm{C}$ for optimum growth.

Detection and distribution of caffeine catabolites and proposed pathway of caffeine degradation The starter culture was produced growing the bacteria in liquid M9-CAF $(1 \mathrm{~g} / \mathrm{l})$ for $18 \mathrm{~h}$ at $28^{\circ} \mathrm{C}$. Two hundred microliters of this starter culture was used to inoculate Eppendorf tubes containing $800 \mu \mathrm{l}$ of M9-CAF $(0.3 \mathrm{~g} / 1)$ and $25 \mathrm{kBq}$ of $\left[{ }^{14} \mathrm{C}-2\right]$ caffeine or $29 \mathrm{kBq}$ of $\left[{ }^{14} \mathrm{C}-2\right]$ xanthine. Other set of Eppendorf tubes contained the same mixture, except that labeled caffeine was replaced by unlabeled at $1 \mathrm{~g} / 1$ concentration. The tubes were held horizontally in an orbital shaker $\left(200 \mathrm{rpm}, 28^{\circ} \mathrm{C}\right)$. For those tubes where only unlabeled caffeine was present, aliquots were taken after 9, 12, 27, 33, 36 and $48 \mathrm{~h}$ of incubation. When labeled compounds were added, only one sample was taken after $27 \mathrm{~h}$. The cells were harvested by centrifugation at full speed in a bench-top centrifuge (Eppendorf, model 5415C) and the supernatants kept at $-20^{\circ} \mathrm{C}$ until analysis. The compounds released in the medium were analyzed by reversed-phase high-performance liquid chromatography (RP-HPLC) with UV detection (270 $\mathrm{nm}$ ), as described by Berthou et al. (3), using a Pharmacia HPLC system. For the assay with labeled caffeine $5 \mu \mathrm{g}$ of each methylxanthines (7-methylxanthine, 3-methylxanthine, 1-methylxanthine, 3,7-dimethylxanthine theobromine, 1,3-dimethylxanthine - theophylline, 3,7-dimethylxanthine - paraxanthine and 1,3,7-trimethylxanthine - caffeine), methyluric acids (7-methyluric acid, 3,7-dimethyluric acid, 1,3-dimethyluric acid, 1,7-dimethyluric acid), xanthine and uric acid were added to the samples and the peaks were collected directly in scintillation vials, dried at $60^{\circ} \mathrm{C}$ and the radioactivity determined after addition of scintillation fluid. Alternatively, for some samples assayed with labeled caffeine, the detection was performed in a radioactivity monitor (model 1208 Betacord, Reeve Analytical, Glasgow, UK). In the assays with labeled xanthine, the compounds were separated by RP-HPLC with the same column indicated above, using $0.5 \%$ aqueous acetic acid $(\mathrm{V} /$ $\mathrm{V})$ as isocratic solvent at a flow rate of $1 \mathrm{ml} / \mathrm{min}$. Internal standards $(5 \mu \mathrm{g})$ of allantoic acid, allantoin, xanthine and uric acid were added to the samples. In 
this case two runs were carried out, the first for the detection of xanthine and uric acid $(270 \mathrm{~nm})$ and the second for allantoin and allantoic acid $(210 \mathrm{~nm})$. The peaks were collected, dried and the radioactivity determined after addition of scintillation fluid.

Characterization and determination of kinetic parameters of xanthine oxidase - Crude protein extracts were used for the characterization and determination of the kinetic parameters. Proteins were extracted from cells of $12 \mathrm{~h}$ cultures grown in Luria Broth medium containing $1 \mathrm{~g} / 1$ caffeine. The cells were pelleted by centrifugation $(4,400 \mathrm{X} \mathrm{g} / 10 \mathrm{~min}$, $4^{\circ} \mathrm{C}$ ), resuspended in a small volume of $25 \mathrm{mM}$ Na-phosphate buffer, pH 7.5, containing $10 \mathrm{mM}$ $\beta$-mercaptoethanol. The cells were disrupted by sonication $(5 \times 15 \mathrm{sec}$, with 2 min intervals on ice) and the debris eliminated by centrifugation $(28,200$ $\mathrm{X} \mathrm{g} / 20 \mathrm{~min}, 4^{\circ} \mathrm{C}$ ). The supernatant was filtered on PD-10 G-25 Sephadex minicolumns (Pharmacia), using $25 \mathrm{mM}$ Na-phosphate buffer $\mathrm{pH} 7.5$ containing $10 \%$ glycerol for elution, and the protein concentration was determined with a ready-to-use BioRad protein reagent. Increasing amounts of protein $(20-200 \mu \mathrm{g})$ were separated by native discontinuous polyacrylamide electrophoresis (PAGE) with $5 \%$ and $10 \%$ of polyacrylamide in the stacking and in the main gel, respectively, and incubated with or without addition of $\mathrm{NAD}^{+}(13)$, for determination of its dependence. Alternatively, in order to detect NADH-diaphorase activity, NADH was included in the incubation buffer. As a blank, one lane was not loaded with protein. A single blue band, formed by the reduction of nitrobluetetrazolium salt, appearing only in the gel that was not incubated with $\mathrm{NAD}^{+}$or NADH, characterized the enzyme as a xanthine oxidase (E.C. 1.2.3.2, type $\mathrm{O}$ enzyme), here on referred to as XO.

The substrate specificity was determined by PAGE as above. The activity was tested with caffeine, theobromine, theophylline, paraxanthine, monomethylxanthines (1-, 3- and 7-methylxanthine) and hypoxanthine. In some cases the gels were left to develop for several hours.

The best protein concentration for in vitro activity was obtained in a reaction mixture containing protein, obtained as above, $150 \mu \mathrm{M}$ of xanthine and $1.1 \mathrm{kBq}$ of $\left[{ }^{14} \mathrm{C}-2\right]$ xanthine, with the final volume adjusted to 200 $\mu 1$ with $25 \mathrm{mM}$ Na-phosphate buffer, $\mathrm{pH}$ 7.5. The incubation proceeded by $30 \mathrm{~min}$ at $30^{\circ} \mathrm{C}$ in Eppendorf tubes. The reaction was stopped by addition of $5 \mu \mathrm{l}$ of $1 \mathrm{M}$ zinc acetate and the supernatant recovered after centrifugation in a bench-top centrifuge was analyzed by RP-HPLC for the production of labeled uric acid. This compound was separated by RP-HPLC with the same column indicated above, using $0.5 \%$ aqueous acetic acid $(\mathrm{v} / \mathrm{v})$ as isocratic solvent at a flow rate of $1 \mathrm{ml} / \mathrm{min}$. Internal standard $(5 \mu \mathrm{g})$ was added to the samples and the corresponding peak at $270 \mathrm{~nm}$ was collected, dried and the radioactivity determined after addition of scintillation fluid.

The optimum reaction time, temperature and $\mathrm{pH}$ were determined in in vitro assays as described above. The $K_{\mathrm{m}}$ for xanthine was determined in a Lineweaver-Burk plot with data from in vitro assays where xanthine was added at different concentrations.

The molecular weight of $\mathrm{XO}$ was determined by PAGE. One lane was loaded with the bacterial protein extract and the other with bovine serum albumin (BSA). After electrophoresis, the gel was cut in two halves. The one with the BSA was stained with Coomassie Blue GR-250 and the other was used for XO activity (13). The first gel had its size restored to the size of the gel for enzyme activity by addition of water in the destaining solvent, and by side-by-side comparison of the gels it was possible to determine the Rf of XO and compare it with those of BSA.

The isoelectric point of $\mathrm{XO}$ was determined by chromatography focusing of crude protein extracts, as described in the next item, and by electrofocusing using a Rotofor electrophoresis (BioRad). The fractions collected from the Rotofor had the $\mathrm{pH}$ measured and $\mathrm{XO}$ activity detected in PAGE, after increasing the $\mathrm{pH}$ of the fractions to near 6 with 250 $\mathrm{mM}$ Tris- $\mathrm{HCl}, \mathrm{pH} 7$.

Purification of XO - XO was purified by liquid chromatography and UV detection $(280 \mathrm{~nm})$ in a Pharmacia HPLC system. During all the purification steps, the activity of XO was tested in PAGE, since several fractions could be rapidly assayed at the same time. In most of the cases the activity reaction was developed after the running front (bromophenol blue) had run half way along the main gel. The purification was carried out at $4^{\circ} \mathrm{C}$ and all buffers used contained $10 \%$ glycerol.

Proteins were extracted from the pellet obtained from $25 \mathrm{~L}$ culture growing in 1:1 LB/M9-CAF $(1 \mathrm{~g} / \mathrm{l})$ medium for $48 \mathrm{~h}$. The extraction buffer was the same used for the characterization and kinetic parameters. The crude extract was desalted in Sephadex G-25 columns ( $70 \mathrm{ml}$ bed volume) and the proteins separated in an anionic exchanger column (DE-52, Beckman, $3 \mathrm{~cm} \times 12 \mathrm{~cm}$ ), using a gradient of $0-0.5$ $\mathrm{M} \mathrm{NaCl}$ in $25 \mathrm{mM}$ Na-phosphate buffer, $\mathrm{pH} 7$, at a 
flow rate of $3 \mathrm{ml} / \mathrm{min}$ was carried out in $60 \mathrm{~min}$. Three minutes $(9 \mathrm{ml})$ fractions were collected, the protein concentration determined with the BioRad reagent and assayed for XO activity in PAGE. The fractions showing the highest activities were pooled, desalted on Sephadex G-25 and the proteins separated in a Mono Q HR5/5 column (Pharmacia), using a gradient of $0-0.5 \mathrm{M} \mathrm{NaCl}$ in $25 \mathrm{mM} \mathrm{Na}$-phosphate buffer, $\mathrm{pH}$ 7 , at a flow rate of $0.75 \mathrm{ml} / \mathrm{min}$, developed in $40 \mathrm{~min}$. Fractions were collected every $2 \mathrm{~min}(1.5 \mathrm{ml})$ and after determination of protein concentration they were assayed for XO in PAGE. The fractions with the highest activities were pooled, desalted and the proteins separated in a Mono P HR 5/5 column (Pharmacia). The proteins were eluted from the column with a $30 \mathrm{~min} \mathrm{pH}$ gradient from 7.1 to 4 using Polybuffer PBE74 (LKB-Pharmacia). Two-minute fractions $(1.5 \mathrm{ml})$ were collected for additional 20 min after the end of the gradient. The $\mathrm{pH}$ and the protein concentration of each fraction were determined and $\mathrm{XO}$ assayed by PAGE. The same fraction was subject again to PAGE using larger combs. Part of the gel was stained with Coomassie Blue GR250 (30 min of staining at $30^{\circ} \mathrm{C}$ and $2 \times 15$ min destaining) and the other half for XO activity. Despite the presence of other proteins, by side-by-side comparison of the gels it was possible to see a distinct band in the Coomassie Blue stained gel. This was excised from the gel, transferred to an Eppendorf tube and ground with a rod after addition of $100 \mu 1$ of $50 \mathrm{mM}$ Tris-HCl buffer, $\mathrm{pH} 7.9$, containing $200 \mathrm{mM} \mathrm{NaCl}$. The tube was left shaking at $4^{\circ} \mathrm{C}$ for $48 \mathrm{~h}$, and the polyacrylamide residues removed by centrifugation in a $0.22 \mu \mathrm{m}$ Amicon Micropure separator. An aliquot of the eluted protein was subjected to RP-HPLC, in order to verify its purity. The protein was separated in a $\mathrm{C}_{18}$ Bio-Sil ODS column (Bio-Rad, $250 \mathrm{~mm}$ x $4.6 \mathrm{~mm}, 5 \mu \mathrm{m}$ ) with UV detection at $220 \mathrm{~nm}$. Solvent $\mathrm{A}$ was aqueous $0.1 \%$ trifluoroacetic acid and solvent B was $30 \%$ of solvent $\mathrm{A}$ in acetonitrile, and the gradient was $0-100 \%$ of solvent $\mathrm{B}$ in $60 \mathrm{~min}$. The remaining protein eluted from the PAGE gel was subjected to denaturing electrophoresis (SDS-PAGE, $10 \%$ polyacrylamide in the main gel) and stained with $\mathrm{AgNO}_{3}(11)$.

The XO purification was repeated twice, with identical results.

\section{RESULTS}

Caffeine degradation pathway - The results of the experiment where cells were cultivated only with unlabeled caffeine $(1 \mathrm{~g} / \mathrm{l})$ are shown in Table 1 . After $9 \mathrm{~h}$ cultivation $20 \%$ of the caffeine had been degraded, showing the high ability of the $P$. putida $\mathrm{L}$ to use this alkaloid as the only source of C and N. After $33 \mathrm{~h}$ very few caffeine was detected in the medium. A transient increase was observed for the other compounds detected by RP-HPLC. It is interesting to observe that highest concentrations of paraxanthine and theobromine, which are the first degradation products of caffeine according to Blecher and Lingens (4), were observed at $12 \mathrm{~h}$ of cultivation. This occurred later $(27 \mathrm{~h})$ for 7-methylxanthine, 7-methyluric acid and xanthine, suggesting that they are formed from demethylation and oxidation of the dimethylxanthines. The monomethyluric acid remained at the same concentration after $27 \mathrm{~h}$. Even by increasing the sensitivity of the UV monitor or injecting larger samples in the HPLC we were not able to detect other caffeine derivatives.

Table 2 shows the results when labeled and unlabeled caffeine were included in the culture medium. We choose $27 \mathrm{~h}$ of culture here taking into account the results obtained in the previous experiment. Until the elution of uric acid, the eluate

Table 1. Caffeine and other methylxanthine concentrations (mg/l) in the culture media supplemented with $1 \mathrm{~g} / \mathrm{l}$ of caffeine.

\begin{tabular}{lcccccc}
\hline & \multicolumn{6}{c}{ Incubation time } \\
& $9 \mathrm{~h}$ & $12 \mathrm{~h}$ & $27 \mathrm{~h}$ & $33 \mathrm{~h}$ & $36 \mathrm{~h}$ & $48 \mathrm{~h}$ \\
\hline Xanthine & 0.18 & 0.24 & 0.34 & 0.19 & 0.09 & $\mathrm{nd}^{*}$ \\
7-Methylxanthine & 4.04 & 25.00 & 52.13 & 0.11 & nd & nd \\
7-Methyluric acid & 0.96 & 3.84 & 7.84 & 9.11 & 8.98 & 9.06 \\
Theobromine & 43.82 & 81.00 & 72.43 & nd & nd & nd \\
Paraxanthine & 0.86 & 1.68 & 1.59 & nd & nd & nd \\
Caffeine & 792.59 & 634.22 & 238.13 & 0.26 & nd & nd \\
\hline
\end{tabular}

${ }^{*}$ nd $=$ not detected 
from the column was collected and the radioactivity also determined (solvent front), probably representing the compounds derived from uric acid degradation. The data presented in Table 2 show the percent recovery of the total radioactivity detected in the fractions collected from the column, on average $59.7 \%$ of the radioactivity given $(25 \mathrm{kBq})$. This difference may probably be due to the degradation of caffeine to $\mathrm{CO}_{2}$. Compounds that were not detected in the assays with unlabeled caffeine could be observed here, such as 3,7- and 1,7-dimethyluric acids, formed by the oxidation of theobromine and paraxanthine, respectively. Using a radioactivity monitor, whose sensitivity was above $0.02 \mathrm{kBq}$, it was not possible to detect any other peak of radioactivity.

Table 2. Percent distribution of radioactivity in caffeine/xanthine metabolites in the culture media supplemented with labeled caffeine/ xanthine and unlabeled caffeine. Means of two independent experiments are presented.

\begin{tabular}{lc}
\hline & Radioactivity Distribution (\%) \\
\hline & Labeled caffeine \\
Solvent front & $93.7 \pm 1.00$ \\
Uric acid & $4.90 \pm 0.81$ \\
Xanthine & $0.20 \pm 0.02$ \\
$7 \mathrm{MU}^{*}$ & $0.85 \pm 0.14$ \\
$7 \mathrm{MX}$ & $0.20 \pm 0.05$ \\
$3,7 \mathrm{DMU}$ & $0.06 \pm 0.01$ \\
1,7DMU & $0.10 \pm 0.01$ \\
Theobromine & $0.04 \pm 0.00$ \\
& Labeled xanthine \\
Solvent front & $99.6 \pm 0.05$ \\
Allantoin & $0.12 \pm 0.00$ \\
Allantoic acid & $0.20 \pm 0.05$ \\
Uric acid & $0.09 \pm 0.01$ \\
Xanthine & $0.05 \pm 0.01$ \\
\hline
\end{tabular}

${ }^{*}=7$-methyluric acid $=7 \mathrm{MU}, 7$-methylxanthine $=7 \mathrm{MX}, 3,7-$ dimethyluric acid =3,7DMU, 1,7-dimethyluric acid = 1,7DMU. $\pm=$ Standard error

When labeled xanthine was included in the media (Table 2) we could detect radioactivity in xanthine, uric acid, allantoin and allantoic acid. The data presented in Table 2 were calculated as previously for labeled caffeine. The total radioactivity collected was $71.0 \%$ of the radioactivity given $(29 \mathrm{kBq})$. Higher radioactivities were found in the ureides allantoin and allantoic acid, confirming at least up to this point that the degradation pathway in our $P$. putida strain is similar to that found by Blecher and Lingens (4) in their studies.
Characterization and kinetic parameters of XO The enzyme responsible for xanthine oxidation was established as an oxidase. Substrate specificity was tested in PAGE and, besides the natural substrates xanthine and hypoxanthine, bands of activity in the same position in the gels were observed only for 3-methylxanthine and theophylline (data not shown), which are not involved in the caffeine degradation pathway. Whereas $10-15$ min were needed for the appearance of the bands with xanthine and hypoxanthine, almost $1 \mathrm{~h}$ was necessary with 3 -methylxanthine and $3 \mathrm{~h}$ with theophylline. For the latter, a very weak band was observed.

XO activity was linear between 20 and $60 \mathrm{~min}$. The optimum protein concentration for in vitro assays, temperature and $\mathrm{pH}$ were, respectively, $14-28 \mu \mathrm{g}$ protein, $30^{\circ} \mathrm{C}$ and $\mathrm{pH}$ 7.0. Good activities were also observed with $\mathrm{pH}$ 8.0. Based on these results all further assays were carried out with $30 \mu \mathrm{g}$ of protein, $30 \mathrm{~min}$, $30^{\circ} \mathrm{C}$ and Na-phosphate buffer, $\mathrm{pH}$ 7.0.

The $K_{\mathrm{m}}$ determined for XO was $169 \mu \mathrm{M}$, and the apparent molecular weight, determined by PAGE, was $192 \mathrm{kDa}$ (Fig. 3C). The pI of XO determined in the Rotofor and Mono P column were 3.1 and 4, respectively.

Purification of XO - XO was purified after two anionic (DE52 and Mono Q) and one chromatofocusing columns (Fig. 2A-C). More intense $\mathrm{XO}$ activity was found in the first column in three fractions, between 0.35 and $0.41 \mathrm{M}$ of the $\mathrm{NaCl}$ gradient (Fig. 2A). These fractions were applied in the Mono Q column (Fig. 2B), most of the activity being eluted from this column in two fractions, between 0.35 and $0.37 \mathrm{M} \mathrm{NaCl}$. These fractions were loaded in the Mono P column and only one fraction from this column, corresponding to $\mathrm{pH} 4$, showed XO activity (Fig. 2C). This fraction was submitted again to PAGE with a continuous comb and half of the gel was stained with Coomassie Blue GR250 and the other half for XO activity. Side-by-side comparison of the gels revealed a distinct band in the Coomassie Blue stained gel (Fig. 3A). This band was eluted from the gel and an aliquot of the eluted protein was subjected to RP-HPLC, a very sensitive technique, in order to evaluate its purity. The Fig. 4 shows that a single peak was detected, indicating that elution from the PAGE gel yielded a pure protein. The eluted protein was also subjected to SDS-PAGE with silver staining (Fig. 3B). We found three subunits $(71,65.6$ and $61.8 \mathrm{kDa})$, whose sum $(198.4 \mathrm{kDa})$ is in agreement with the molecular weight estimated by PAGE (192 kDa). 


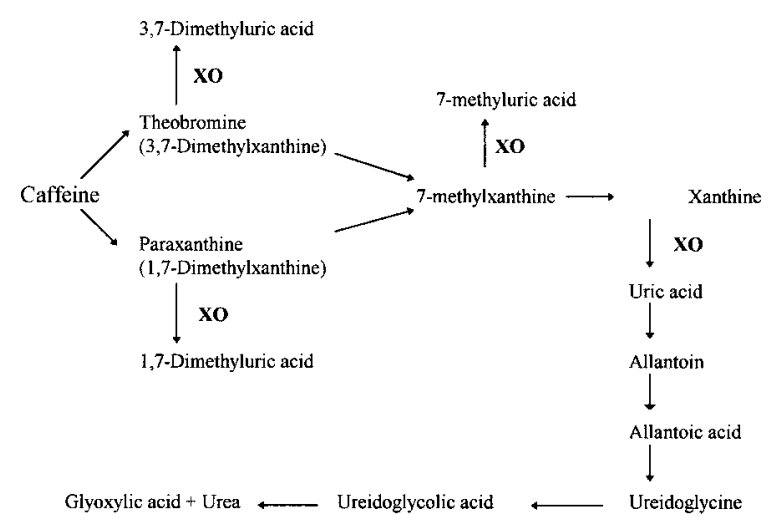

Figure 1. Caffeine degradation pathway in Pseudomonas putida. $\mathrm{XO}$ indicates the reactions mediated by xanthine oxidase.

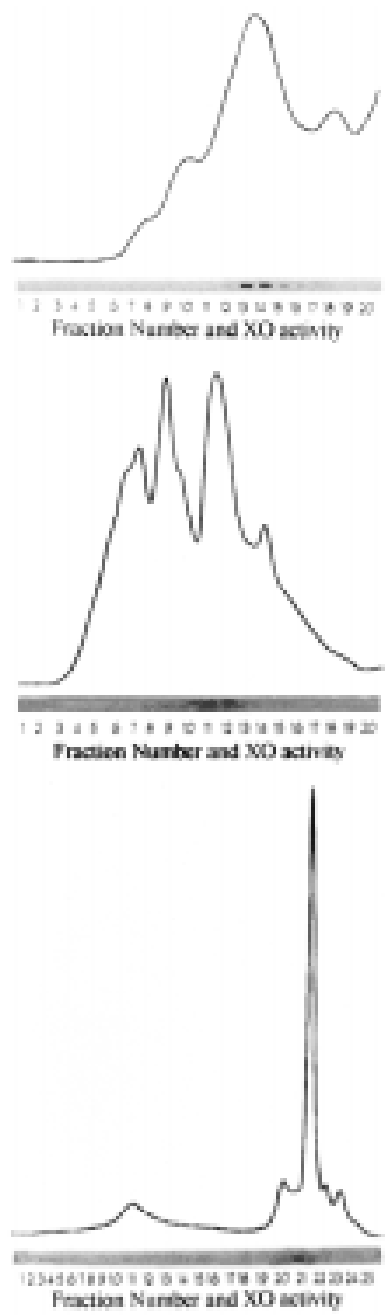

Figure 2. Protein elution profiles from chromatographies in DEAEcellulose (A), Mono Q (B) and Mono P (C) columns. XO activity in the fractions was detected in PAGE and they are shown at the bottom of each chromatography.

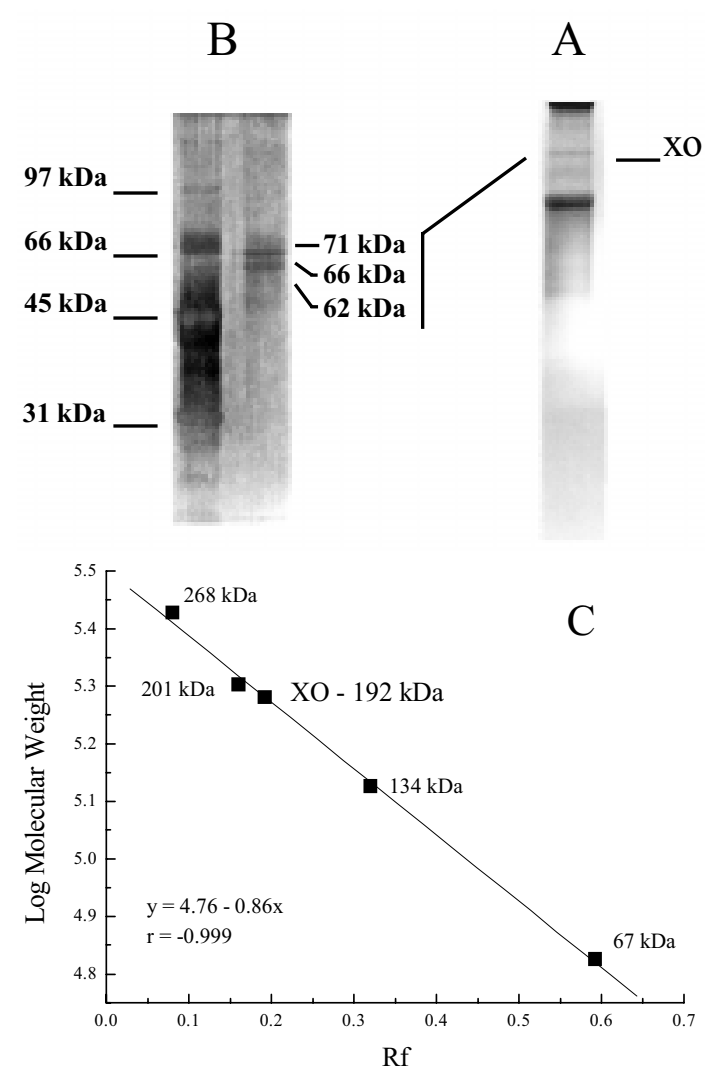

Figure 3. Coomassie blue protein profile staining of PAGE of the fraction from the Mono P column, where a band corresponded to the band of activitity of a parallel active staining gel (A), SDS-PAGE of the eluted band from the coomassie blue stained PAGE gel (B), and $M_{\mathrm{r}}$ determination on PAGE gel using paralleled gels for active staining and coomassie blue staining of BSA non denatured (C). Molecular markers are indicated in the left lane of $B$.

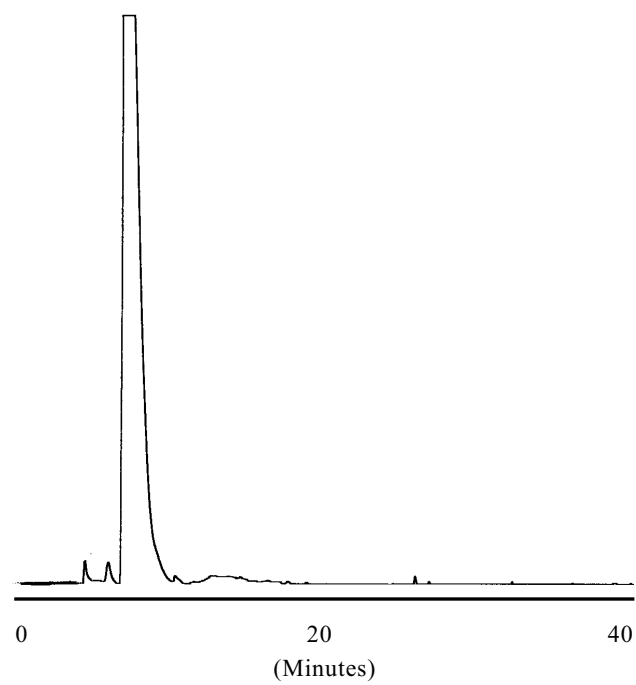

Figure 4. Reversed-phase high-performance liquid chromatography of XO eluted from the PAGE gel. 
Although an accurate native molecular weight can not be determined by one polyacrylamide concentration the data obtained are very similar.

\section{DISCUSSION}

Previous studies carried out with induced mutants for caffeine degradation showed that dimethylxanthines and monomethylxanthines, formed by sequential caffeine demethylation, might be oxidized to their respective methyluric acids (4), as seen in Fig. 1. Recently, we have isolated P. putida strains displaying a very high ability to degrade caffeine (18) and experiments carried out here with the strain L, with non labeled and labeled caffeine, showed the same caffeine catabolic pathway. Therefore, the higher ability of our strain to grow on very high caffeine concentrations is not related to an alternative catabolic route but probably due to its own metabolic efficiency in breaking down the alkaloid.

Blecher and Lingens (4) observed that during the caffeine degradation, very small amounts of methyluric acids were released in the medium (3 - 5 $\mathrm{mg} / 1$ for 7-methyluric acid, $1 \mathrm{mg} / 1$ for 3,7-dimethyluric acid). For the detection of 1,7-dimethyluric acid, it was necessary to grow the bacteria in medium containing 1,7-dimethylxanthine as the sole source of carbon and nitrogen, instead of caffeine. Even using this approach, they still obtained an amount enough only for thin layer chromatography identification by co-chromatography with an authentic sample. The other methyluric acids were characterized additionally by infrared and mass spectroscopy. In the three cases they started from 1 to $10 \mathrm{~L}$ culture media.

Here, using more sophisticated techniques (HPLC and labeled caffeine), which enabled us to work with low volumes of media, we could also show that, in addition to the similar caffeine catabolic pathway, the P. putida $\mathrm{L}$ also accumulated more 7-methyluric acid than 3,7-dimethyluric and 1,7-dimethyluric acid, which was not further degraded. Similar to the results of Blecher and Lingens (4), there was no bacterial growth and decrease in concentration when these methyluric acids were separately included in media culture as sole sources of carbon and nitrogen, indicating the high substrate specificity of uricase. However, our data from growing $P$. putida $\mathrm{L}$ with labeled caffeine showed higher radioactivity in 1,7-dimethyluric acid than 3,7-dimethyluric acid.

Xanthine oxidase have a wide substrate specificity. Active staining of PAGE electrophoresis showed that
XO from $P$. putida $\mathrm{L}$ was able to oxidize xanthine, hypoxanthine, 3-methylxanthine and theophylline. Woolfolk (15) prepared cell-free extracts from xanthine and caffeine grown cells of induced mutants of $P$. putida for caffeine degradation and used them in a ferricyanide-linked dehydrogenases assay against several methylxanthines. For both extracts higher activities were observed with xanthine, 3-methylxanthine and 1-methylxanthine. Activities with 7-methylxanthine, theobromine, theophylline and paraxanthine were observed only with caffeine grown cell extracts, however, much lower than those previously mentioned methylxanthines. Although Woolfolk (15) had observed that molecular oxygen was essential for active methylxanthine degradation in cell suspension experiments, it is not possible to suggest an oxidase activity since further work $(2,8)$ showed that different cytochrome P450 activities, an enzyme dependent of oxygen, were involved in the demethylation of caffeine, theobromine and 7-methylxanthine. However, studies with $S$. marcescens, which presented a very similar caffeine catabolic pathway with $P$. putida, showed xanthine dehydrogenase nonspecificity against several methylxanthines (9).

Our data show that for the P. putida strain $\mathrm{L}$ isolated by Yamaoka-Yano and Mazzafera (18) a xanthine oxidase is responsible for the oxidation of xanthine, and probably, methylxanthines, however with much less efficiency. Woolfolk and Downard (17) examined protein extracts from a diverse collection of xanthine-metabolizing bacteria with respect to their ability to oxidize xanthine, 1- and 3-methylxanthine in the presence of NAD or oxygen as electron acceptors. They found that among the gram-negative bacteria, Pseudomonas seemed to have two activities, a particulate oxidase and a soluble dehydrogenase, as already suggested by these authors in a previous work (15). In the particulated fraction an oxygen-dependent xanthine oxidase was detected, and in the soluble fraction a NAD-dependent and a ferricyanide-linked xanthine dehydrogenase were found. The particulate fraction was obtained from a second centrifugation at higher speed with the supernatant obtained from a first lower centrifugation force with sonicated cells. Interestingly, the particulate activity was found exclusively in cells grown with xanthine. All activities remained in the supernatant in extracts prepared from caffeine-grown cells during the preparation of the particles (15).

In a following work Woolfolk (16) separated these 
two activities and purified a ferricyanide-linked xanthine dehydrogenase concluding that the apparent molecular weight of the enzyme was $255 \mathrm{kDa}$, a trimer/ tetramer of $77 \mathrm{kda}$ subunits. Active staining on PAGE of the enzyme showed two main bands, somewhat overlapping.

Here protein extracts were obtained from cells grown exclusively in caffeine. Therefore one might suggest that we were dealing with the three enzymes detected by Woolfolk in his studies. However, since $\mathrm{NAD}^{+}$was not needed for detection of activity in PAGE with active staining and in the in vitro assays, we probably have purified the oxygen-dependent enzyme form. Moreover, during the purification in the anionic (DE52 and Mono P) chromatofocusing columns we have always observed only one peak of activity, represented by a single sharp band in PAGE electrophoresis. In addition, a single protein peak was detected with RP-HPLC and the molecular weight determined was consistent with the sum of the three subunits detected by SDS-PAGE with silver staining.

The metabolic and physiological role of the enzyme purified is debatable. We did not observe any bacterial growth when methyluric acids were added as the sole source of carbon and nitrogen in the medium as well as the concentration of 7-methyluric acid was stable even after caffeine depletion of the medium. With respect with the other methyluric acids, low levels of radioactivity in 3,7- and 1,7-dimethyluric acid were observed in the assays with labeled caffeine, after $27 \mathrm{~h}$ of culture, suggesting a very low degradation rate or, supported by the lack of bacterial growth in their presence, accumulation in very small amounts. Consequently, we might presume that $\mathrm{XO}$ has a higher specificity for 7-methylxanthine among the methylxanthines whose methyluric acids detected here. Therefore, the formation of these compounds may be considered as a consequence of the wide substrate specificity of XO. This is reinforced by the fact that activity in PAGE gels were also observed with 3-methylxanthine and theophylline, which are not metabolites of caffeine degradation in P. putida, as observed here and by Blecher and Lingens (4).

\section{ACKNOWLEDGMENTS}

The authors thank Conselho Nacional de Desenvolvimento Científico e Tecnológico - CNPq for a post doctoral (D.M.Y.Y.) and a research fellowship (P.M.). This work was partially supported by Fundação de Amparo à Pesquisa do Estado de São Paulo - FAPESP - grant 95/3743-4.

\section{RESUMO}

\section{Catabolismo de cafeína e purificação de xantina oxidase responsável pela produção de ácidos metilúricos em Pseudomonas putida $\mathrm{L}$}

O catabolismo de cafeína e a enzima xantina oxidase, envolvida na sua degradação, foram estudados em Pseudomonas putida L, uma linhagem com alta capacidade para utilizar este substrato como fonte de energia. Células crescidas na presença de cafeína e xantina marcadas com ${ }^{14} \mathrm{C}$, e cafeína não marcada, mostraram que este alcalóide foi degradado via teobromina/paraxantina -> 7-metilxantina -> xantina -> ácido úrico -> alantoína -> ácido alantóico. Ácidos metilúricos foram formados a partir de teobromina, paraxantina e 7-metilxantina, embora nenhum crescimento bacteriano ter sido observado quando estes compostos foram usados como substratos, indicando que a xantina oxidase possui um ampla especificidade para substratos. Isto foi confirmado por detecção de atividade em gel não desnaturante (PAGE), tendo sido observada atividade para teofilina e 3-metilxantina, que não estão envolvidas na degradação de cafeína. Uma única banda de atividade foi observada em (PAGE) quando $\mathrm{NAD}^{+}$não foi incluído no meio de incubação, indicando ser a enzima uma oxidase. A temperatura ótima e o $\mathrm{pH}$ ótimo da reação para a enzima foram $30^{\circ} \mathrm{C}$ e 7,0 , respectivamente. $\mathrm{O} K_{\mathrm{m}}$ determinado foi de $169 \mu \mathrm{M}$, e o pI 3.1 - 4.0. A massa molecular determinada através da comparação lado a lado de gel de atividade em PAGE e PAGE de padrão de albumina de soro bovino foi de $192 \mathrm{kDa}$, que foi coincidente com a soma $(198,4 \mathrm{kDa})$ de três subunidades $(71,65,6$ e $61,8 \mathrm{kDa})$ da enzima purificada.

Palavras-chave: ácidos metilúricos, cafeína, metilpurinas, Pseudomonas, xantina oxidase.

\section{REFERENCES}

1. Asano, Y.; Komeda, T.; Yamada, H. Microbial production of theobromine from caffeine. Biosci. Biotech. Biochem. 57:1286-1289, 1993.

2. Asano, Y.; Komeda, T.; Yamada, H. Enzymes involved in theobromine production from caffeine by Pseudomonas putida No. 352. Biosci. Biotech. Biochem. 58:2303-2304, 1994. 
3. Berthou, F.; Ratanasavanh, D.; Riche, C.; Picart, D.; Voirin, T.; Guillouzo A. Comparison of caffeine metabolism by slices, microsomes and hepatocyte cultures from adult human liver. Xenobiotica 19:401-417, 1989.

4. Blecher, R.; Lingens, F. The metabolism of caffeine by a Pseudomonas putida strain. Hoppe-Seyler's Z. Physiol. Chem. 358:807-817; 1977

5. Dikstein, S.; Bergmann, F.; Henis, Y. Studies on uric acid and related compounds. IV. The specificity of bacterial xanthine oxidases. J. Biol. Chem. 224:67-77, 1957.

6. Glück, M.; Lingens, F. Studies on the microbial production of theobromine and heteroxanthine from caffeine. Appl. Microbiol. Technol.25:334-340, 1987.

7. Heftmann, E. Synthesis of caffeine-2- ${ }^{14} \mathrm{C}$. J. Labelled Compounds 7:463-465, 1971

8. Hohnloser, W.; Osswald, B.; Lingens, F. Enzymological aspects of caffeine demethylation and formaldehyde oxidation by Pseudomonas putida C1. Hoppe-Seyler's Z. Physiol. Chem. 361:1763-1766, 1980

9. Mazzafera, P.; Olsson, O.; Sandberg, G. Degradation of caffeine and related methylxanthines by Serratia marcescens isolated from soil under coffee cultivation. Microb. Ecol. 31:199-207, 1996.

10. Middelhoven, W.J.; Lommen, A. Degradation of caffeine by Pseudomonas putida C3024; the effect of oxygen concentration. Antonie van Leeuwenhoek 50:298-300, 1984.
11. Oackley, N.R.; Kirsch, D. R.; Morris, N. R. A simplified ultrasensitive silver stain for detecting protein in polyacrylamide gels. Anal. Biochem. 105:361-363, 1980.

12. Sambrook, J.; Fritsch, E. F.; Maniatis, T. Molecular Cloning: $a$ Laboratory Manual. Vol 1. Cold Spring Harbor Laboratory Press, Cold Spring Harbor, New York, 1989, 420p.

13. Vallejos, C.E. Enzyme activity staining. In: Tanksley, S.D.(ed), Isozymes in Plant Genetics and Breeding, Part A. Elsevier Science Publishers, Amsterdam, 1983, p. 469-516.

14. Vogels, G.D.; van der Drift, C. Degradation of purines and pyrimidines by microorganisms. Bacteriol. Rev. 40:403-468, 1976.

15. Woolfolk, C.A. Metabolism of N-methylpurines by a Pseudomonas putida strain isolated by enrichment on the caffeine as sole source of carbon and nitrogen. J. Bacteriol. 123:1088-1106, 1975

16. Woolfolk, C.A. Purification and properties of a novel ferricyanide-linked xanthine dehydrogenase from Pseudomonas putida 40. J. Bacteriol. 163:600-609, 1985.

17. Woolfolk, C.A.; Downard, J. S. Distribution of xanthine oxidase and xanthine dehydrogenase specificity types among bacteria. J. Bacteriol. 130:1175-1191, 1977 .

18. Yamaoka-Yano, D.M.; Mazzafera, P. Degradation of caffeine by Pseudomonas putida isolated from soil. J. Allelopathy 5: 23-34, 1998. 